\title{
Impact of Mahatma Gandhi National Rural Employment Guarantee Act (Scheme) on Unemployment and Village Economy (A Case Study of Mandor Block of Jodhpur District)
}

\author{
Kshitiz Maharshi, Swati Vashisth, Neelam Shekhawat
}

\begin{abstract}
The basic means of promoting improvement of village economy have been to increase employment, open doors to the unemployed and under-use human resources. A diverse training process has been put in place to meet the needs of the poor by guaranteeing their fundamental rights and encouraging new unexpected household developments. To combat unemployment, desperation and job security with a multiplier seminar on the social capital system, physical capital, and ecological synergies, strengthening the democratic process and ensuring sustainable development, another program with clear pay was organized. National Rural Employment Guarantee Act (NREGA) in 2005 and jointly implemented the states and organizational spaces of India in a course that was sponsored from February 2006. With its authentic cluster work and rights-based methodology, the National Gandhi Rural Employment (MGNREGA) grants every 100 days of safe work a farm. The MGNREGA is said to have raised and sustained the standard of people of village economy but as obvious questions are being raised on its reality rather than paper. This research paper aims to find out the effectiveness of the aforesaid programme on combating unemployment and improving the soul of India i.e. villages. For these purpose 50 grampanchayats of Mandor Block of Jodhpur District of Rajasthan state has been selected for the study and both primary data and secondary data was collected and analyzed using charts. The secondary data was collected from the website of government that provides data about MGNREGA and tabulated effectively to provide a conclusion about the impact of the programme and its weaknesses along with the suggestions if required.
\end{abstract}

Keywords: MGNREGA, Physical Capital, Social Capital, Unskilled Manual Work

\section{INTRODUCTION}

In the past, the government has done this. Understood how this affects the return to work at the tables in the labor market.

Manuscript received on March 12,2021

Revised Manuscript received on March 22,2021

Manuscript published on March 30, 2021.

* Correspondence Author

Dr. Kshitiz Maharshi,* Assistant Professor, Department of Business Finance \& Economics, Jai Narain Vyas (State) University, Jodhpur (Rajasthan), India.

Swati Vashisth, Research Scholar, Department of Business Administration, Jai Narain Vyas (State) University, Jodhpur (Rajasthan), India.

Neelam Shekhawat, Research Scholar, Department of Accounting, Jai Narain Vyas (State) University, Jodhpur (Rajasthan), India.

(c) The Authors. Published by Blue Eyes Intelligence Engineering and Sciences Publication (BEIESP). This is an open access article under the CC BY-NC-ND license (http://creativecommons.org/licenses/by-nc-nd/4.0/)
One of the massive efforts in this direction is the conclusion of the Agreements related to the Gandhi National Rural Employment Guarantee Law of 2005 (MGNREGA).

MGNREGA could also be a considerable improvement to confirm the selection for work and strengthen the professional security of family units in normal areas of the country. The plan provides 100 guaranteed pay days per year in each role for each parent whose truly capable individual volunteers can perform basic manual labor. Unemployment continues to deter the poor and the MGNREGA plan helps them get out of the sensation trap indefinitely.

The MGNREGA program was done after various government business programs were made considering the picked debilitation and distinction tormenting the commonplaces of India. MGNREGA is a marvelous essential work plot on the earth. They gave central purposes of this system are:

- social interest;

- the methodology of solid resources, (for example, water security, soil affirmation, higher land abundance) through the certifiable work drove by the prepared experts;

- work of disturbed prepared experts, for example, ladies, SC and ST; and

- Careful improvement in like manner India through the blueprint's effect on expert consistency and commendation based fortifying.

\section{RESEARCH METHODOLOGY}

The respondents they selected for evaluation were MGNREGA beneficiaries from Mandor Square in Jodhpur. To make sure the portion of the gram panchayats was 50, not of it. The accumulated responses received were 35 which was satisfactory as $70 \%$ datawas collected from the target group. Initially the respondents were hesitated in sharing information but they gained the objective of the survey meanwhile which helped in conducting efficient research. Of these respondents, approximately $78.13 \%$ completed the exam. Among these, some have been regularly considered legitimate and therefore chosen to ponder knowledge.

Published By:

Blue Eyes Intelligence Engineering

\& Sciences Publication

(C) Copyright: All rights reserved. 


\section{Data Collection and Analysis}

The targeted information was collected using graphics and individual parts from the MGNREGA website of the government. A prepared report was used to request responses on the effects of MGNREGA. Optional sources of information included the internet, magazines, newspapers and books from various libraries and government agencies were also used in collecting data. The arrangement of the knowledge was completed by the attributes of the recipient. With the help of SPSS, real statistical equipment was used and tables and charts were used to show the comparative analysis or trend of the various aspects pertaining to unemployment removal and village economy. Chi-Square test was used to evaluate the impact.

\section{OBJECTIVES OF THE STUDY}

The broad objectives of the study include and not restricted to the following:

- To audit the effect of MGNREGA on unemployment and village economy in Mandor block of the Jodhpur district of Rajasthan.
- To get the bottlenecks within the usage of MGNREGA and suggest the ways of removing those bottlenecks.

- To propose philosophy for sensible execution of MGNREGA in Rajasthan.

- To find out the problems and the root causes of such problems

1. Analysis of Impact of MNREGA on Unemployment and Village Economy in Mandor Block of Jodhpur

$74 \%$ respondents tended to that their pay was broadened and from there on buying force and uses besides expanded due to MGNREGA. It is a market-request beginning course of action considering the way that their all-inclusive pay drives a premium for the yield and their jumping at the chance to burn-through increments. MGNREGA brings money related headway comparatively as monetary new turn of events. While then again $26 \%$ respondents offered a clarification to this solicitation in negative. It is a huge commitment to awkward compensation work at a colossal degree in the provincial zones of the country.

Hypothesis statements and Data Analysis

H0: There is no significant relationship between overall well being of beneficiaries and employment opportunities.

Table 1 Chi square test

\begin{tabular}{|l|l|l|l|l|}
\hline $\begin{array}{l}\text { Hypothesis } \\
\text { There is no significant relationship between overall well being of } \\
\text { beneficiaries and employment opportunities. }\end{array}$ & Value & D.f & Sig & Status \\
\hline
\end{tabular}

Table 2 portrays the assessment of information by utilizing chi square tests. The dismissal of speculation demonstrated that there is an association between when everything is said in done flourishing of a recipient and business openings gave by MGNREGA. From this time forward, it will with everything considered be said that business openings gave by MGNREGA are adding to the overall succeeding of recipients.

H0: Capacity building has an insignificant relationship with the well being of beneficiaries.

Table 2 Chi square test

\begin{tabular}{|l|l|l|l|l|}
\hline $\begin{array}{l}\text { Hypothesis } \\
\text { Capacity building has an insignificant relationship with the well } \\
\text { being of beneficiaries. }\end{array}$ & Value & D.f & Sig & Status \\
\hline
\end{tabular}

The hypothesis showing the link between the beneficiaries' marginal work and its fulfillment was confirmed in the same way (Table 3). The rejection of the theory shows that MGNREGA's cut-off work contributes to the general good of the beneficiaries. With anything viewed as performance pointing to another unexpected financial turnaround, speculation suggests that MGNREGA will make a significant contribution to beneficiaries' monetary improvement. The rejection of speculation therefore clearly shows that MGNREGA expects a functional part to be made up of common spaces by mixing their status in relation to cash. Still a colossal piece of them feel that the occupation they used to beat MGNREGS is only foundation of sarapanch. Verifiably, even from time to time it was discovered that the individuals who are truly weakened of those cards have not gotten the cards. While humbly couples of tenants who are working in open zones have taken business cards and is not a minuscule touch following position. A scramble of the Muslim ladies guaranteed that as the Sarapanch is having a spot with ST social requesting he has pardoned their energy for card in regularly. At any rate considering deterrent of Block Development Officer usually generally not many of them got the card. An Index was given to think about the idea different rights and procedures of the course of action, for example affirmation of occupation for 100 days, Statutory least wages, work on income, joblessness settlement, 33\% work for female recipients and essentially unclear wages for people, and so on, Responses of the recipients concerning care about these rights and approaches were gathered utilizing five-point Likert's scale ( 1 for marvelously unprotected idea and 5 for sublime idea). Mean assessment of the reactions concerning these plans gives the force for the Index. As such Index respects relating to every respondent were assembled. To review the effect of care level of recipients on their joint effort in the plan, a Linear Regression model was utilized and invalid hypothesis, viz., Ho: Awareness level of ladies recipients about MGNREGA has no essential effect on their piece of slack all through movement, was attempted.

Published By:

Blue Eyes Intelligence Engineering

\& Sciences Publication

(C) Copyright: All rights reserved.

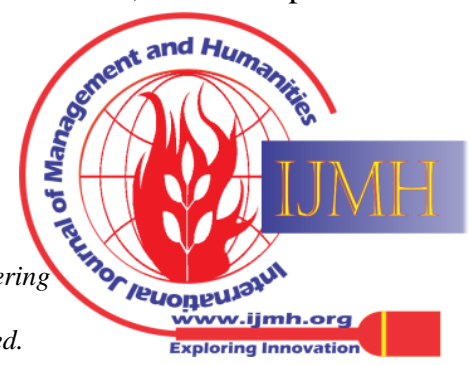


Workdays $=\alpha+\beta$ (Awareness $)+€$ The record of care level about MGNREGA was taken as independent variable and

yearly customary broad stretches of business accommodated test respondents was taken as down and out factor.

Table 3 Coefficients for the Equation

\begin{tabular}{|c|c|c|c|c|c|c|c|}
\hline \multirow{2}{*}{ Model } & \multicolumn{2}{|c|}{$\begin{array}{c}\text { Unstandardized } \\
\text { Coefficients }\end{array}$} & $\begin{array}{c}\text { Standard } \\
\text { Coefficients }\end{array}$ & \multirow{2}{*}{$\mathrm{t}$} & \multirow{2}{*}{ sign } & \multicolumn{2}{|c|}{$\begin{array}{c}\text { 95\% confidence interval } \\
\text { for B }\end{array}$} \\
\cline { 7 - 8 } & $\mathrm{B}$ & $\begin{array}{c}\text { Std } \\
\text { error }\end{array}$ & Beta & & & $\begin{array}{c}\text { Lower } \\
\text { Bound }\end{array}$ & $\begin{array}{c}\text { Upper } \\
\text { Bound }\end{array}$ \\
\hline (Constant) & -30.735 & 4.41 & & -10.96 & .000 & -39.55 & -21.92 \\
\hline Awareness & 23.01 & 1.69 & .719 & 21.91 & .000 & 19.62 & 26.40 \\
\hline
\end{tabular}

The evaluation of union coefficient among restless and free factor is .719 which watches out for solid positive straight relationship. The apostatize coefficient relating to mind level is positive and p appraisal of $t$ assessment is gigantic ( $\mathrm{p}<.05)$ and which gathers that care level about MGNREGA has positive and enormous effect on assistance of recipients in MGNREGA. Month brisk Labor watchful Person days Projection report.

Table 4 Comparative Month Wise Labour and Work Projections

\begin{tabular}{|c|c|c|c|c|c|c|c|c|c|c|c|c|}
\hline Year & April & May & June & July & Aug & Sept & Oct & Nov & Dec & Jan & Feb & March \\
\hline $2017-18$ & 69777 & 115640 & 133956 & 81291 & 19352 & 6446 & 7236 & 16580 & 58163 & 69864 & 67075 & 45017 \\
\hline $2018-19$ & 68654 & 118024 & 124878 & 69690 & 16169 & 6855 & 6641 & 12436 & 43121 & 65349 & 57299 & 33942 \\
\hline $2019-20$ & 69903 & 113241 & 123450 & 75540 & 19806 & 9243 & 6180 & 16467 & 55656 & 84671 & 76846 & 46238 \\
\hline $2020-21$ & 107743 & 134843 & 130328 & 62909 & 15229 & 9442 & 9780 & 21312 & 53239 & 116331 & & \\
\hline
\end{tabular}

Source:http://mnregaweb4.nic.in/netnrega/state_html/lb_mon_rptippe.aspx

From the above table it very well may be accepted that the work or business projections have associated in fundamentally continually from FY 2019-20 to FY 2020-21 which was dormant in 2018-19 and 2017-20.

\section{Chart 1 Chart showing the trends of Labour Projection}

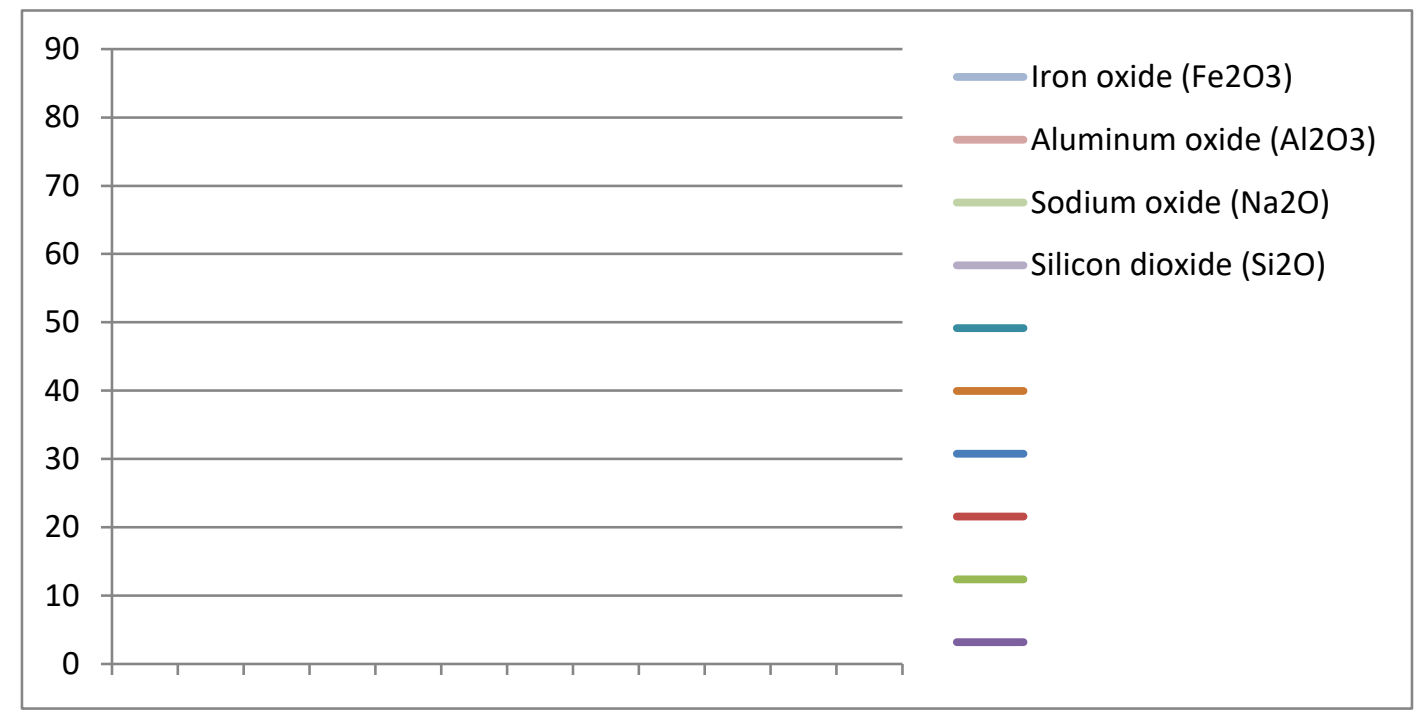

Table 5 Family Wise Attendance Criteria during 3 years

\begin{tabular}{|c|c|c|c|c|c|c|}
\hline & $\begin{array}{c}\text { Total } \\
\text { Attendanceb } \\
\text { etween } 1 \text { to } \\
\text { 30 days }\end{array}$ & $\begin{array}{c}\text { Total } \\
\text { Attendancebet } \\
\text { ween 31 to 60 } \\
\text { days }\end{array}$ & $\begin{array}{c}\text { Total } \\
\text { Attendanceb } \\
\text { etween } 61 \text { to } \\
90 \text { days }\end{array}$ & $\begin{array}{c}\text { Total } \\
\text { Attendanceb } \\
\text { etween } 91 \text { to } \\
120 \text { days }\end{array}$ & $\begin{array}{c}\text { Total } \\
\text { Attendancebet } \\
\text { ween } 121 \\
\text { to150 days }\end{array}$ & $\begin{array}{c}\text { Total } \\
\text { attendance }\end{array}$ \\
\hline $2018-19$ & 4868 & 3865 & 4411 & 1097 & 175 & 14416 \\
\hline $2019-20$ & 3735 & 3978 & 4648 & 2749 & 0 & 15110 \\
\hline $2020-21$ & 6290 & 7023 & 1857 & 0 & 0 & 15170 \\
\hline
\end{tabular}

Source: https://mnregaweb2.nic.in/netnrega/homestciti.aspx

From the above table it will everything considered be seen that the work gave by the MNREGA make helps in improving the town economy other than in wide all out yet the workers require to give more basic event to this procedure as the number continues lessening with the improvement in full scale number of days.

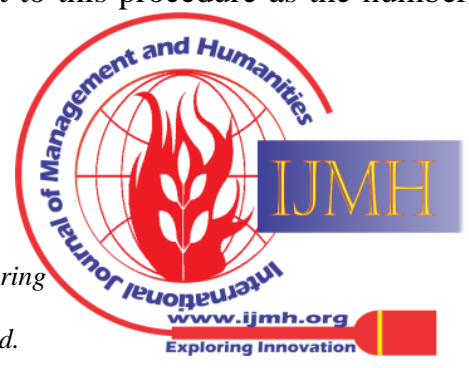


Impact of Mahatma Gandhi National Rural Employment Guarantee Act (Scheme) on Unemployment and Village Economy (A Case Study of Mandor Block of Jodhpur District)

\section{Chart 2 Chart showing Family Wise Attendance Criteria during 3 years}

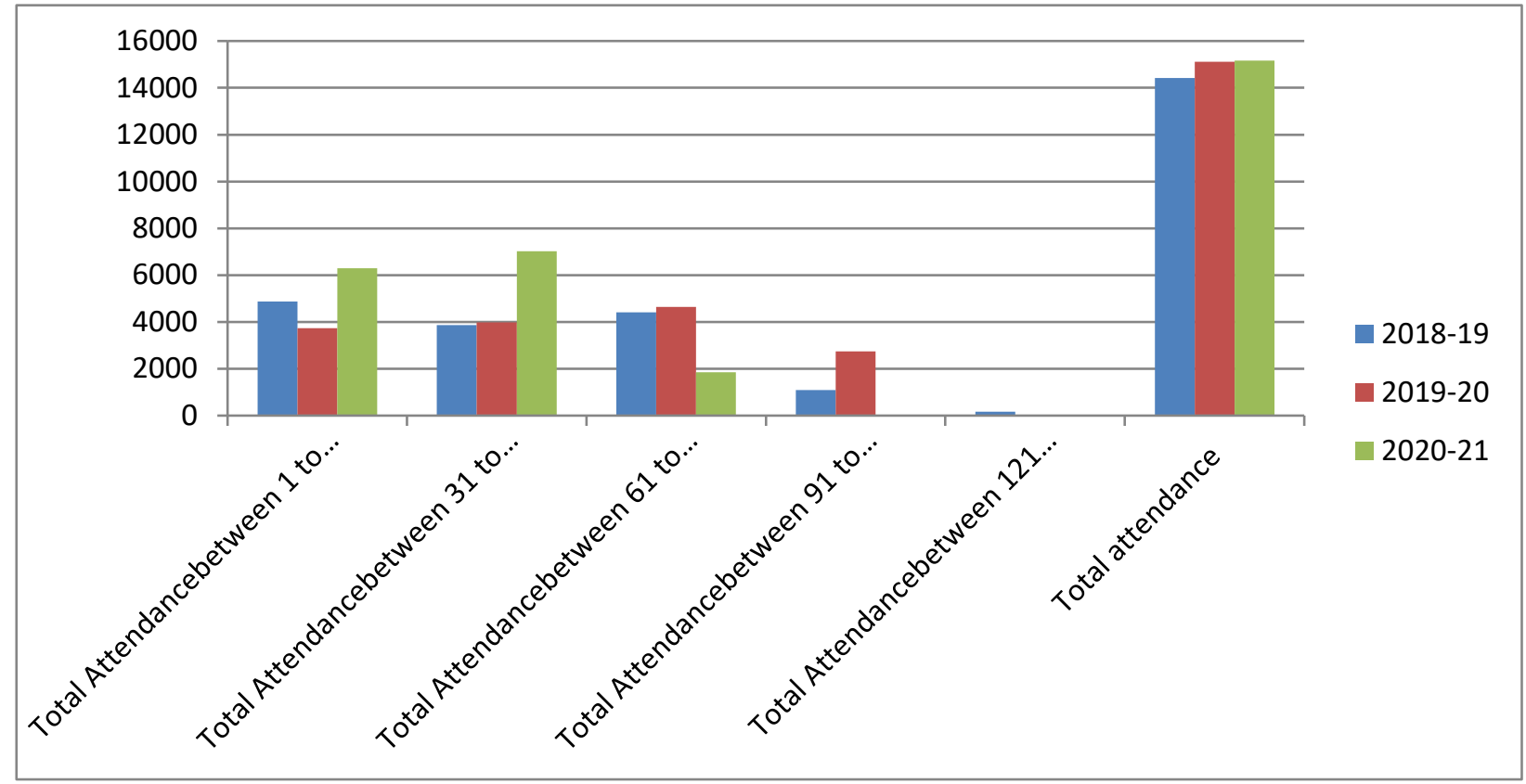

Table 6 Person day wise Attendance Criteria during 3 years

\begin{tabular}{|c|c|c|c|c|c|c|}
\hline & $\begin{array}{c}\text { Total } \\
\text { Attendancebetw } \\
\text { Year } 1 \text { to 30 days }\end{array}$ & $\begin{array}{c}\text { Total } \\
\text { Attendancebet } \\
\text { ween 31 to 60 } \\
\text { days }\end{array}$ & $\begin{array}{c}\text { Attendancebetw } \\
\text { een } 61 \text { to } 90 \\
\text { days }\end{array}$ & $\begin{array}{c}\text { Attendancebetwee } \\
\text { n 91 to 120 days }\end{array}$ & $\begin{array}{c}\text { Attendancebetw } \\
\text { een 121 to150 } \\
\text { days }\end{array}$ & $\begin{array}{c}\text { Total } \\
\text { attendance }\end{array}$ \\
\hline $2018-19$ & 83292 & 174757 & 364136 & 109700 & 20003 & 751888 \\
\hline $2019-20$ & 61436 & 177030 & 383290 & 274900 & 0 & 896656 \\
\hline $2020-21$ & 114466 & 303643 & 133488 & 0 & 0 & 551597 \\
\hline
\end{tabular}

Source: https://nrega.raj.nic.in/pdmn/yojanaprogressreport.aspx

From the above table it will generally be seen that the work gave by the MNREGA envision helps in improving the town economy additionally in wide outright yet the experts need to give more perceptible event to this game plan as the number continues diminishing with the improvement in full scale number of days.

Chart 3 Chart showing Person day wise Attendance Criteria during 3 years

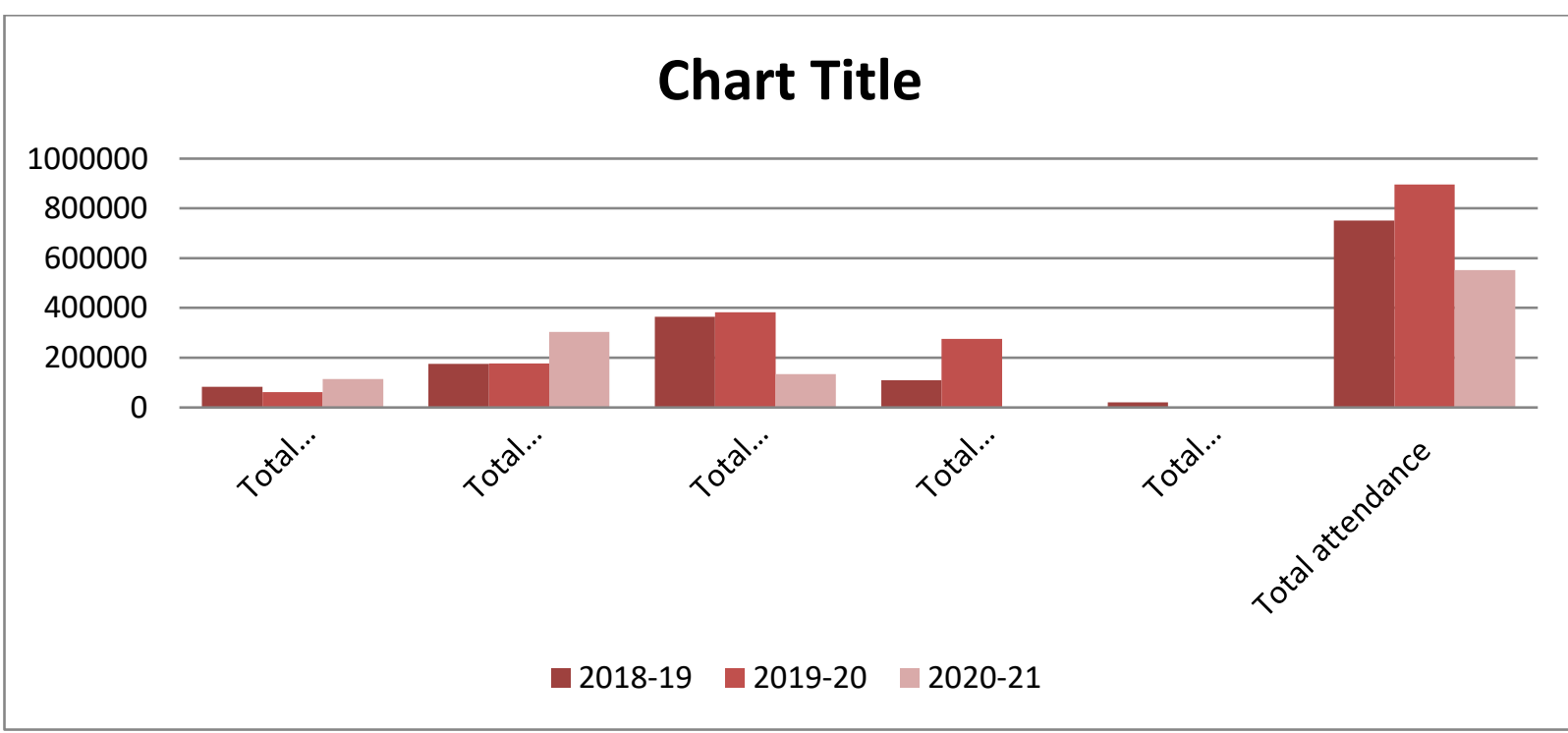

Disabled persons given employment

Published By:

Blue Eyes Intelligence Engineering

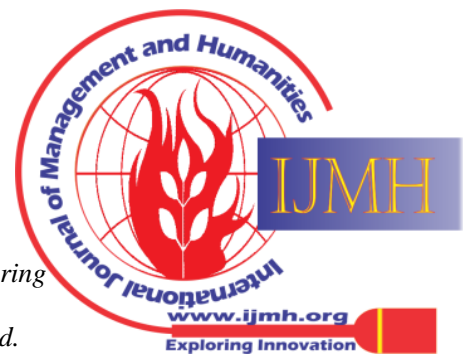




\begin{tabular}{|c|c|c|}
\hline $\begin{array}{c}\text { No. of Disabled persons registered } \\
\text { in NREGA }\end{array}$ & $\begin{array}{c}\text { No. of Disabled persons worked in } \\
\text { NREGA in FY 2019-20 }\end{array}$ & $\begin{array}{c}\text { Person days Generated in FY 2019- } \\
20\end{array}$ \\
\hline 126 & 40 & 1484 \\
\hline
\end{tabular}

Source: https://mnregaweb2.nic.in/netnrega/homestciti.aspx

It will everything considered be closed from the above table that the MNREGA plot is celebrated among the debilitated people too in any case crucial enrollment won't help so an idea should be given by the panchayats sets out as toward advantageous use of the procedure.

\section{New Employment Generated under MNREGA during the current year}

\begin{tabular}{|l|l|l|}
\hline Families that have worked earlier & $\begin{array}{l}\text { Families that have registered } \\
\text { themselves in FY 2019-2020 }\end{array}$ & Total families \\
\hline 18498 & 1133 & 19631 \\
\hline
\end{tabular}

Source: https://mnregaweb2.nic.in/netnrega/homestciti.aspx

\section{Status of Labour Budget}

Out of 50 gram panchayats only35 i.e. 70\% were entered for labour projections while the remaining 15 i.e. $30 \%$ were not entered for labour projections. It very well may be done up from the above table that some Gram panchayats are not taking MNREGA with most astounding reality. Definitely, even they don't careful their occupants to share during the time spent considering a replacements and work projections which is done disappointment at the degree of Gram panchayats and hampers the turn of events and possible results of Mandor Block

\section{Chart 4 Chart showing more than 100 days Employment}

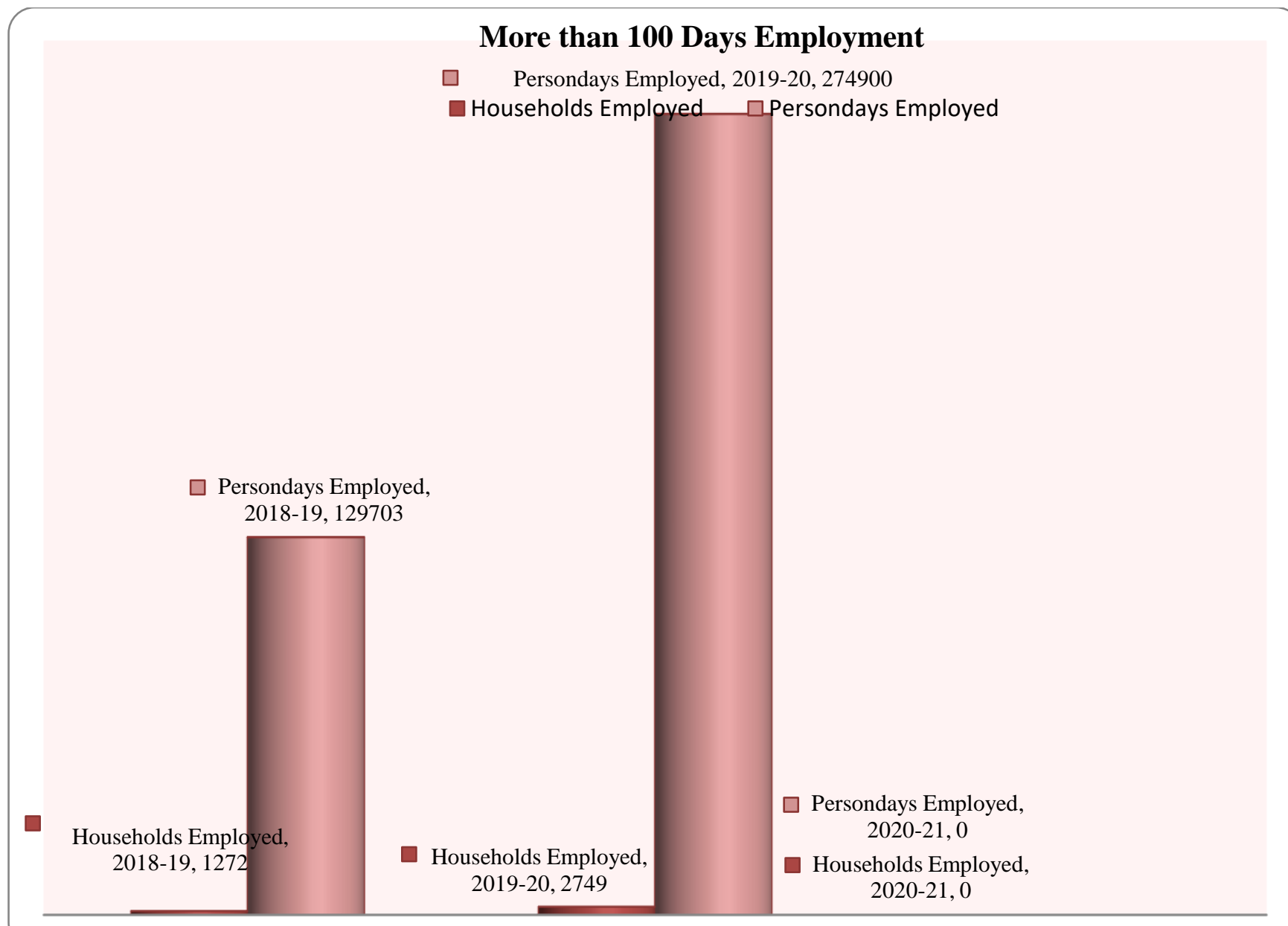

\section{SUMMARY OF FINDINGS}

The evaluation showed that MGNREGA has regularly influenced individuals and habitats. In these selected gram panchayats, different inclinations are made, e.g. B.
Published By:

Blue Eyes Intelligence Engineering

\& Sciences Publication

(C) Copyright: All rights reserved.

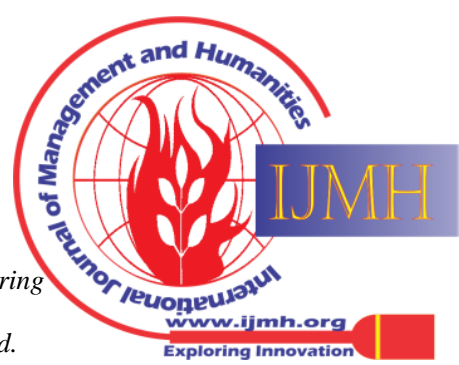


Water security, water use, tree heritage, soil protection, upgrading of normal water, advancement of land, availability and control of land, and then more thought about MGNREGA, the Gram and the Panchayats in the same way wisely established as the Standard People ran the business. MGNREGA's work could be of fundamental help to families who are essentially nothing and to peripheral pastoralists who are alarming and massive about wages and have only part of the income. This research found evidence that normal women feel empowered and look like men. MGNREGA's work has not isolated people in terms of wages. This truth was the essential certification for women. During the evaluation, a large number of women who were present on the MGNREGA website reported improvements in their living and working rules. Thanks to MGNREGA, they were able to make a living on their own wages and without the help of their husbands. Before MGNREGA, they did not see such opportunities to work on an equal footing with people and stayed mainly because of the attached housewives. MGNREGA is the ultimate show that created these basic strategies that everyday people use to make themselves feel better and better.

\section{CONCLUSION}

The current evaluation shows that if the MGNREGS is perceived a scale and executed well it can diminish urgency at rock bottom level also because it can interface with the poor within the short run. The multiplier evaluation has shown the various delayed consequence of MGNREGS on preferred position, course and monetary upliftment within the examination zone. From the above assessment it's incited that the presentation of MGNREGA isn't full satisfying. It has failed to reach the poorer due to predominant corruption and politics however the beneficiaries cannot be completely denied. The course of action couldn't guarantee the 100 days work affirmation to most of the cardboard holders. Clearly, even we saw that the methodology bombs horribly in regard of giving work roads to the jobless during an incredible turn of events. MGNREGA is accomplishment foundation during the entire presence of state controlled retirement support in India after a promising circumstance. Maintained after a useful battle for a whole business ensures law, this sale could also be a fragmentary triumph towards a wise decision to work. In spite of how MGNREGA could also be a very totally broke down, a shocking asset within the requirement with regard to ordinary occupants to urge their focal occupation, in any case its poor performance denies the people poor from their central rights. The assessment disclose that within the face of various issues, MGNREGA could also be a program that has given valuable placetoladiesin thesocietyafter this, ladies have begun taking involvement within the family matters and nature of encountering cash. Regardless, care truly keeps on being a firm test; ladies in evaluation territory have gotten positive for dynamic understudies and people within the plans. Change got to be made at ground levels within the turn of events. Due idea got to be taken for profitable execution of the game-plan. Thus a proper policy for its good execution is required otherwise the programme is well designed to take the village economy to greater heights.

\section{SCOPE FOR FURTHER RESEARCH}

Studies are occasionally driven in various squares of Jodhpur space of Rajasthan or various zones of Rajasthan. It might be particularly enrapturing to arrange another evaluation inside a basically indistinguishable area of examination, with the breaker of more endeavors and thusly the more divisions, which may give more joined result direct and better utility to the topic specialists and the heads. An evaluation establishing distinctive socio-area and bio-socio factors is are finding the opportunity to be captivating to search after out the impact of certifiable culture on word related prospering, mechanical security and tidiness, etc

\section{REFERENCES}

1. Yadav Kritika, Parmar Mahesh (2017); Analysis of Mahatma Gandhi National Rural Employment Guarantee Act Using Data Mining Technique; International Journal of Computational Intelligence Research Volume 13, Number 9 pp. 2221-2235

2. Mir Mohd Ashraf, Azad Suheel, Doorwar Dr. Vibha (2018); Impact of Mahatma Gandhi National Rural Employment Guarantee Act (MGNREGA) on Unemployment and Village Economy; International Journal of trend in scientific research and development (IJTSRD), Vol 2 Issue 4

3. Bahuguna Rahul, Pandey Akhilesh Chandra, Soodan Vishal (2016); A Study On Socio Economic Impact Of Mgnrega On Beneficiaries In Rudrapryag Block Of Uttarakhand India; International Journal Of Management And Applied Science, ISSN: 2394-7926. Volume-2, Issue-10

4. FarooqiSaleem Akhtar, Saleem Prof. Imran (2015); "Impact of Mahatma Gandhi National Rural Employment Guarantee Act (MGNREGA) on the Life of Women Living under Poverty"- A Study of Block Aligarh, Uttar Pradesh; Pacific Business Review International Volume 8, Issue 4

5. Borah Kabita, BordoloiRimjhim (2014); MGNREGA and its Impact on Daily Waged Women Workers: A Case study of Sonitpur Block of Assam; IOSR Journal of Economics and Finance (IOSR-JEF), pISSN: 2321-5925.Volume 4, Issue 4. PP 40-44

6. Girish Kumar Agarwal (2019); Mahatma Gandhi National Rural Employment Guarantee Act: Design Failure, Implementation Failure or Both; SAGE Journals

7. D. Narasimha Reddy, A. Amarender Reddy \& M. C. S. Bantilan (2014) The Impact of Mahatma Gandhi National Rural Employment Guarantee Act (MGNREGA) on Rural Labor Markets and Agriculture, India Review, 13:3, 251-273

8. Khan Dr. Mohammad Israr, Saxena Savita (2016); Economic impact of MGNREGA: A case study of Bisalpur sub-division of block Pilibhit in Uttar Pradesh; International Journal of Multidisciplinary Research and Development Volume 3; Issue 10; October; Page No. 131-136

9. MohantySoumya (2012);Mahatma Gandhi National Rural Employment Guarantee Act (MGNREGA) and Tribal Livelihoods: A Case Study in Sundargarh Block of Odisha; National Institute of Technology Rourkela

10. Breitkreuz Rhonda, Stanton Carley-Jane, Brady Nurmaiya, PattisonWilliams John, King E.D.,MishraChudhury, Swallow Brent (2017); The Mahatma Gandhi National Rural Employment Guarantee Scheme: A Policy Solution to Rural Poverty in India?; Development Policy Review

11. http://mnregaweb4.nic.in

12. https://mnregaweb2.nic.in 


\section{AUTHORS PROFILE}

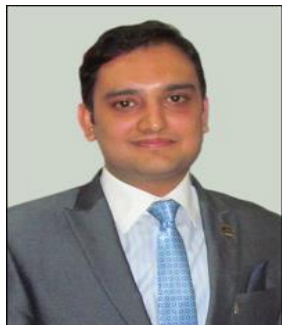

Dr. Kshitiz Maharshi, Assistant Professor, Faculty of Commerce and Management Studies, Jai Narain Vyas University, Jodhpur, obtained his Ph.D. in Finance from University of Rajasthan, Jaipur. He is a renowned Vastu Consultant and an accomplished teacher specializing in Business Finance and Economics. He has a teaching experience of four years. He has been awarded Junior

Research Fellowship in Commerce by University Grants Commission. He has been a key member of organizing committees in various academic events. Under his direction, one national conference on Globalised growth and Indian Economy has been successfully organised. Later, he was instrumental in organising International Conference on Recent Trends in Business Finance and Economics as Deputy Director and Chief Coordinator. He has several national and international research contributions to his credit and he is member in many academic associations.

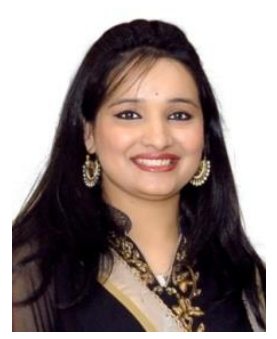

Mrs. Swati Vashisth, has more than two years of experience with the government bodies in implementing IT infrastructure at the grass root level and digitizing the financial transactions in institutions like SHGs, cooperatives and their nodal agencies in states like Rajasthan, Andhra Pradesh and Telangana. She has over a half decade experience in conducting cyber security, analyzing the cyber security postures of various organizations. She has a rich experience and expertise in policy designing, training and development. She has a rich experience of more than five years in research in the field of business administration; and is a member of the DSCI (Data Security Council of India).

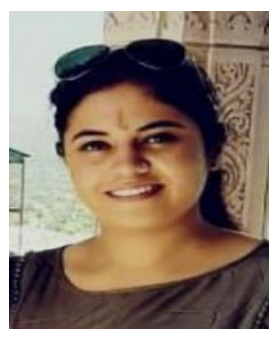

hour.
Miss Neelam Shekhawat, is a Research Scholar at Faculty of Commerce and Management Studies at Jai Narain Vyas (State) University, Jodhpur. Her research for PSU led her to pursue her doctoral research which is contributing in creating awareness about efficient public expenditure. She has research contributions to her credit. With exceptionally good communication skills, she develops into the research work, the art of providing insight depth with various groups according to the need of the

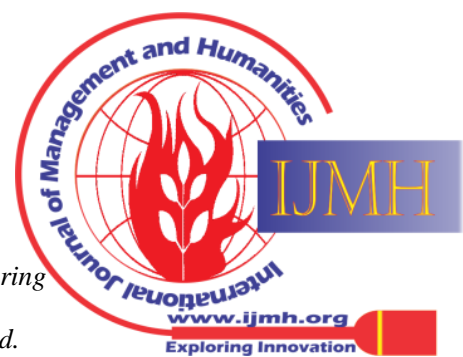

